\title{
HOW EGOVERNMENT CAN CHANGE THE BUSINESS: UKRAINIAN ASPECT
}

\author{
Volodymyr DOVHANYK', \\ Ivan Franko National University of Lviv, Ukraine
}

\begin{abstract}
The purpose of the paper is to evaluate the impact of eGovernment on business and to define the main implementation characteristics of the following systems in Ukraine. Methodology. Statistical data provided by the E-Government Survey and Doing Business index were used for computing the linear regression model. Ordinary least square method was used for defining the model's parameters. The paper review existing approaches to managing eGovernment in EU and Estonia as an example. Analysis of available eGovernment services was done to determine their general characteristics and system's stakeholders. Results of the research demonstrate the strong correlation between the E-Government Index and Doing Business rating. Computed model proves the directly proportional relation between the two indexes and model's accuracy allows to prove statistical significance of the model. The main approaches to term "eGovernment" were reviewed, as well as the most used classifications of E-gov services. Main eGovernment stakeholders were defined and their possible impacts on the project were evaluated. Positive impacts of eGovernment services were summarized and the most significant challenges for Ukrainian business and citizens are listed. Practical implication. Since implementing the software for providing administrative services has positive effect on simplicity of running business research results can be used for defining reform strategies in regulation changes. Defined list of stakeholders should be considered during designing and implementation of eGovernment solution for better understanding the real business needs. The research defines main bureaucratic barriers that slow down the development of e-government in Ukraine. Vale/originality. Defined model enable better understanding the relation between the government regulations and providing administrative services on-line. For the first time the research emphasizes on groups of stakeholders in Ukraine of eGovernment projects, including specialized non-governmental public organizations. The research results can be improved by the inclusion of additional macroeconomic and social indicators in regression model. Also, interaction of stakeholders at all stages of project design and construction of e-government services requires additional studies. Interdependence between stakeholders can be simulated, for example, by using game theory. Summarized challenges and bureaucratic limits for eGovernment (and for ICT at whole) can be used as short-term goals for revising and improving eGovernment policy in Ukraine.
\end{abstract}

Key words: eGovernment, e-Gov, business regulations, Doing Business index, E-Government development index.

JEL classification: $\mathrm{H} 11, \mathrm{~K} 23, \mathrm{~F} 63$

\section{Introduction}

Ukrainian revolution in 2014, President's and Parliament's elections changed the vector of Ukrainian foreign policy as well as social-economic goals that should be reached in the mi-term period. Based on the Strategy of sustainable development "Ukraine-2020" provided by the President of Ukraine in early 2015 one of the key performance indicators for Ukrainian economy is reaching top thirty positions in international ranking Doing Business (Strategy of sustainable development "Ukraine-2020", 2010). Several reforms are considered to achieve this goal however implementation of eGovernment systems can be important component of each declared policies.

\section{2. eGovernment}

Modern academic researches and government agencies provide several definitions of term "electronic government" ("eGovernment" or simple "E-gov"). The World Bank and the United Nations describe eGovernment (E-gov) as the utilization of the Internet and the World Wide Web for delivering government information and services to citizens and other stakeholders in a country (UN Public Administration Program, 2010; InfoDev, 2004). eGovernment makes government's services more effective and accessible to citizens (Moon, 2002; West, 2004). Ukrainian researches defines eGovernment as implementation of the government functions in the way that satisfy all internal and external relations using

Corresponding author:

${ }^{1}$ Department of Information Systems in Management, Ivan Franko National University of Lviv.

Email: vdovganyk@ukr.net 
information and communication technology (ICT) (Dubov, 2006); technology that simplifies and facilitates communication among citizens, business and governance on all levels and in all areas.

In addition, Concept of eGovernment development in Ukraine defines E-gov (Cabinet of Ministers of Ukraine, 2010) as a form of governance organization that promotes efficiency, openness and transparency of state and local government using ICT to create a new type of state, focused on the needs of citizens.

Previous academic researches demonstrate that countries with advanced economic development have better development eGovernment infrastructure than countries with transformation economy (West, 2007; Azad et al., 2010).

Government institutions and academic researches investigate relations between implementation of eGovernment solutions and economy of the state. Dependencies between the macroeconomic indexes and eGovernment maturity were tested and appropriate model was provided (Ifinedo, P. \& Singh, M, 2011). E-Gov Development index report (United Nations Department of Economic and Social Affairs, 2014) analyse impact of Gross National Income on eGovernment state. Based on UN research conclusion that GNI does not have direct influence on eGovernment development was made.

Despite numerous usage of ICT for providing services by government three main types of eGovernment systems can be defined (Jeong, 2007):

- Government-to-Government, G2G - systems that provides data interchanges between different government institutions themselves;

- Government-to-Business, G2B - systems that provides services for business;

- Government-to-Citizen, G2C - systems that provides services directly to citizens.

In recent publication other types ofeGovernmentsystems can be met, like Government-to-Employees, Governmentto-Consumer, Government-to-Organization, Citizen-toCitizen, but all of them can be explained using previously mentioned types.

\section{EU approach to eGovernment}

Each country can have its own eGovernment infrastructure that usually include web-portal for single access to provided services, institution that define eGovernment strategy for the country and support existing systems, list of services available for residents and non-residents, and attributes required for authorization and authentication the citizen or organization. As a result of Lisbon summit in 2000 list of 20 electronic services that should be supported by future EU countries were defined (Dubov, 2006). Among them there were 10 services that satisfy economical rights of citizens and business, such as: - Income taxes: declaration, notification of assessment;

- Job search services by labor offices;

- Social security contributions including unemployment benefits and medical costs (reimbursement or direct settlement);

- Car registration (new, used and imported cars);

- Social contribution for employees;

- Corporation tax: declaration, notification;

- VAT: declaration, notification;

- Registration of a new company;

- Customs declarations;

- Public procurement.

Implementation of required services can incredibly depend on the country. For example Estonia e-Gov portal provides 24 services including both mandatory and complementary services that simplify business transactions in the country (e-Estonia, 2015):

- Several options for electronic identifier (MobileID and Electronic ID cards);

- Government integration bus for data interchange between the systems (XRoad);

- Electronic digital signature;

- Electronic document workflow (DigiDoc).

\section{4. eGovernment impact on economy}

For evaluation general impact of eGovernment on complexity of communication between government authority and business entities we compare E-Government Index (EGI) evaluated annually by the UN Department of Economic and Social Affairs and Doing Business rating provided by World Bank for 2014.

E-Government Indexpresents the state ofE-Government Development of the United Nations Member States. The index provides a holistic view of e-government development resting on three important dimensions: the availability of online services, telecommunication infrastructure and human capacity (United Nations Department of Economic and Social Affairs, 2014).

Since 2002 the Doing Business project provides objective measures of business regulations and their enforcement across 189 economies and selected cities at the subnational and regional level (World Bank, 2013). Major index is decomposed into eleven sub indexes that measures the regulations in different aspects of the business, like starting a business, trading across borders, paying taxis etc.

The official data provided by the UN and World bank were used for the analysis of dependencies between the level of eGovernment development and simplicity of business regulations in the countries. Correlation between E-Government Index and Doing Business sub indexes were calculated to determinate possible relations. For data evaluation both Pearson correlation and rank Spearman correlation were used. The main differences of this approaches is that Spearman's $\rho$ estimates ordered rank on the pairs in the data set. Computation results are provided in Table 1.

Computed correlation allows us to observe strong relations between E-Government Index and Doing Business index. Additionally we can define correlation between EDI and a few sub indexes (Starting a Business and Trading across Borders) based on Spearman coefficients. 
Table 1

\section{Correlation between EDI} and Doing Business sub index

\begin{tabular}{|l|c|c|}
\hline & $\begin{array}{c}\text { Pearson } \\
\text { correlation }\end{array}$ & $\begin{array}{c}\text { Spearman } \\
\text { correlation }\end{array}$ \\
\hline Doing Business index & 0,805 & 0,807 \\
\hline Sub indexes & & \\
\hline Starting a Business & 0,587 & 0,616 \\
\hline Dealing with Construction Permits & 0,270 & 0,258 \\
\hline Getting Electricity & 0,502 & 0,478 \\
\hline Registering Property & 0,505 & 0,548 \\
\hline Getting Credit & 0,498 & 0,508 \\
\hline Protecting Minority Investors & 0,509 & 0,473 \\
\hline Paying Taxes & 0,501 & 0,523 \\
\hline Trading across Borders & 0,580 & 0,694 \\
\hline Enforcing Contracts & 0,578 & 0,566 \\
\hline Resolving Insolvency & 0,712 & 0,683 \\
\hline
\end{tabular}

Ordinary leas square (OLS) method was used for creating a linear regression model. The model measures relations between the E-Government Index (x) and Doing Business Index (y), using the data of 2014. Based on 184 with using the $\mathrm{R}$ package version 3.1 .2 we defined the following model:

$$
y=40.067+45.633 x
$$

Both F-test and t-test for the model's parameters prove statistical significant of the model. We can observe several points that pretty far from the defined linear model (Fig. 1) and have negative impact on model's accuracy $\left(R^{2}=0.648\right)$. However this model proves the tightly relations between the level of eGovernment development and complexity of business regulation in the country.

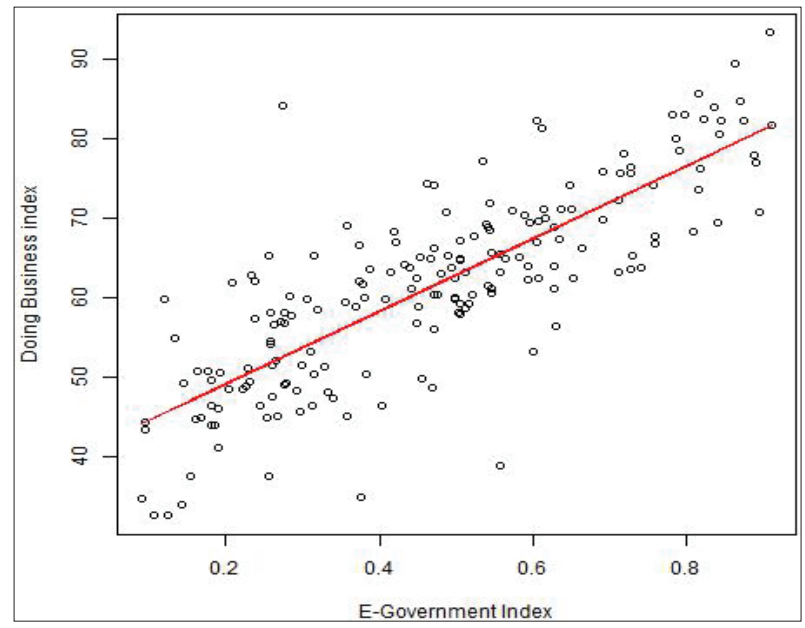

Fig. 1. Dependency between the E-Government Index and Doing Business Index

\section{Characteristics of eGovernment in Ukraine}

During first two decades of Ukrainian independence number of available eGovernment services was definitely limited. Researches emphasize that main reason for that was limited understanding of its need by government officers (Shevchuk, 2003). The necessity and importance of eGovernment were clear only for middle management. Together with restricted Internet access they decelerate eGovernment development in the state. However with increasing Internet infrastructure and changing political authority till the autumn 2015 there are 147 available free eGovernment services provided by state authorities. In addition separate local governments, like Kyiv and Lviv, implements their own eGovernment portals usually with functionality that duplicates functionality of state ones.

Developed and implemented eGovernment systems can be in the following five groups:

- State electronic registries that store and represent information about companies, property rights etc. In some cases such systems provide corresponding certificates.

- eGovernance systems that provides electronic document flow for government institutions and can contain interfaces for citizens or business;

- G2C systems that provides possibility to book time for visit to corresponding office or request the paper certificate;

- Trading systems that enable government to maintain government procurement or sell arrested property on-line; - Electronically reporting services that enables maintain required reports on-line;

- Open data systems that represent aggregated or raw data about different aspects of government activities;

- Web-sites of government institutions that provides main information about regulations in corresponding areas, proposed changes into existing regulations, upcoming events.

Regardless of eGovernment system's type or category it can provide the following benefits for business and whole economy:

- Decreasing time and expenses required for registration new business or maintaining changes for existing one, receiving government permissions or licenses;

- Depersonalizing government services by decreasing number of direct contacts with government officers and as result minimize opportunity for corruption;

- Organizing interaction between business and government in predictable and transparent way;

- Providing reliable and up-to-date statistical information for market, environment, and legislative research by business.

Despite on listed above advantages we should note possible challenges to companies and citizens related to the implementation of eGovernment systems, such as:

- Increasing requirements for employees especially related to usage of computers;

- Necessity of investment in hardware and software, some limitations to software that are supported by the eGovernment solutions;

- Increasing risk of cyber crimes and looses of sensitive personal information.

Important issues of any project is defining stakeholders and understanding their needs. Project Management Institute defines stakeholder as individual, group or organization who may affect, be affected by, or perceive itself to be affected by a decision, activity or outcome of 
the project (Project Management Institute, 2013). During all stages of developing, implementation, and using an eGovernment solution we can define the stakeholders according to the Table 2 .

Unfortunately except ordinary stakeholders and their interests we need to consider impacts of "oldfashion" corrupted officers and their willingness to keep possibilities of corruption actions or get illegal income from implementation of eGovernment project.
Despite obvious benefits of the migration from the traditional providing of government services to eGovernment approach there are several key problems for such transformation:

- Obsolete technical standards defining software development lifecycle. Main standards (GOSTs) are inherited from USSR and are dated 1970s-1980s.

- Discrepancy on Ukrainian and international standards ITC security, which increases efforts for appropriate

Table 2

Main stakeholders of an eGovernment project

\begin{tabular}{|c|c|c|c|}
\hline Stakeholder & Main interests & Examples & $\begin{array}{c}\text { Potential impact } \\
\text { on the E-gov projects }\end{array}$ \\
\hline $\begin{array}{l}\text { Government institutions - } \\
\text { Main owner of the system }\end{array}$ & $\begin{array}{l}\text { Decreasing number of requests from citizens } \\
\text { and another institutions; } \\
\text { Optimization of particular business process in } \\
\text { government organisations; } \\
\text { Implementation of declared policy in } \\
\text { informational environment. }\end{array}$ & $\begin{array}{l}\text { Ministry of Justice of } \\
\text { Ukraine, State Fiscal } \\
\text { Service of Ukraine, local } \\
\text { authorities. }\end{array}$ & $\begin{array}{l}\text { High } \\
\text { Represents Customer and Project } \\
\text { Sponsor in E-gov projects; } \\
\text { Response for defining } \\
\text { requirements to the system and } \\
\text { its acceptance }\end{array}$ \\
\hline Software developers & $\begin{array}{l}\text { Receiving profit from implementation of E-gov } \\
\text { systems; } \\
\text { Satisfy the needs of System's owner; }\end{array}$ & $\begin{array}{l}\text { Software companies } \\
\text { that develop and/or } \\
\text { supports E-gov systems. }\end{array}$ & $\begin{array}{l}\text { High } \\
\text { Response for choosing the } \\
\text { technology and architecture of } \\
\text { the systems }\end{array}$ \\
\hline Hardware providers & $\begin{array}{l}\text { Receiving profit from supplying hardware for } \\
\text { E-gov systems; } \\
\text { Satisfy required levels of System's availability } \\
\text { and security }\end{array}$ & $\begin{array}{l}\text { Companies that } \\
\text { produce or sell } \\
\text { hardware, rarely Cloud } \\
\text { providers }\end{array}$ & $\begin{array}{l}\text { Medium } \\
\text { Effects the infrastructure } \\
\text { solutions available on the market } \\
\text { in appropriate price ranges }\end{array}$ \\
\hline $\begin{array}{l}\text { End users - employees of } \\
\text { government institutions }\end{array}$ & $\begin{array}{l}\text { Decreasing scope of everyday routine job; } \\
\text { Minimizing number of changes related to } \\
\text { existing business processes; } \\
\text { In some cases keeping mechanisms of } \\
\text { corruption. }\end{array}$ & $\begin{array}{l}\text { Officers of centers of } \\
\text { administrative services, } \\
\text { civil registries }\end{array}$ & $\begin{array}{l}\text { Medium } \\
\text { Provides the feedback for } \\
\text { implemented software, maintain } \\
\text { the data required for providing } \\
\text { E-gov services, partially defines } \\
\text { the requirements to the system }\end{array}$ \\
\hline $\begin{array}{l}\text { End users - citizens of } \\
\text { Ukraine }\end{array}$ & $\begin{array}{l}\text { Accelerating receiving the administrative } \\
\text { services; } \\
\text { Decreasing probability of requesting bribes for } \\
\text { providing administrative services; } \\
\text { Decreasing costs for receiving administrative } \\
\text { services }\end{array}$ & $\begin{array}{l}\text { Citizens of Ukraine who } \\
\text { receives administrative } \\
\text { services trough E-gov } \\
\text { systems }\end{array}$ & $\begin{array}{l}\text { Low } \\
\text { Represents the most numerous } \\
\text { group of users. Usually no } \\
\text { involved in the process of } \\
\text { creation E-gov system }\end{array}$ \\
\hline Controlling institutions & $\begin{array}{l}\text { Control target usage of budget; } \\
\text { Identifying and combating acts of corruption } \\
\text { during the creation of eGovernment; } \\
\text { Control for systems consistency with } \\
\text { government technical standards. }\end{array}$ & $\begin{array}{l}\text { State Fiscal Service of } \\
\text { Ukraine, Department } \\
\text { of treasury of Ukraine, } \\
\text { State Service of Special } \\
\text { Communication and } \\
\text { Information Protection }\end{array}$ & $\begin{array}{l}\text { High } \\
\text { Response for defying security } \\
\text { requirements to the software and } \\
\text { validating provided solution. } \\
\text { Controls the budget spending } \\
\text { and procurement procedures }\end{array}$ \\
\hline $\begin{array}{l}\text { NGO working in corruption } \\
\text { avoidance area }\end{array}$ & $\begin{array}{l}\text { Monitoring target usage of budget during } \\
\text { creation of eGovernment systems; } \\
\text { Monitoring information available from open } \\
\text { sources for identifying and avoiding the } \\
\text { corruption. }\end{array}$ & $\begin{array}{l}\text { NGOs working in } \\
\text { corruption avoidance } \\
\text { area ("watchdogs") i.e. } \\
\text { Anti-Corruption Action } \\
\text { Centre }\end{array}$ & $\begin{array}{l}\text { Low } \\
\text { Monitors the government } \\
\text { expenses and escalates identified } \\
\text { problems to Prosecutors. Usually } \\
\text { no involved in the process of } \\
\text { creation E-gov system }\end{array}$ \\
\hline Specialized organisations & $\begin{array}{l}\text { Accessing statistical data about government } \\
\text { activities for further usage in scientific } \\
\text { (marketing) researches. } \\
\text { Accessing statistical data about government } \\
\text { activities for monitoring separate government } \\
\text { services }\end{array}$ & $\begin{array}{l}\text { Patient organisation, } \\
\text { scientific societies, } \mathrm{RnD} \\
\text { groups }\end{array}$ & $\begin{array}{l}\text { Low } \\
\text { Provides feedback about system } \\
\text { usage. Usually no involved in the } \\
\text { process of creation E-gov system }\end{array}$ \\
\hline $\begin{array}{l}\text { Owners of other E-gov } \\
\text { systems }\end{array}$ & $\begin{array}{l}\text { Possibility to integrate the system with existing } \\
\text { e-Gov solutions for reducing manual operations } \\
\text { and data redundancy. }\end{array}$ & $\begin{array}{l}\text { State registry of } \\
\text { vehicles, State registry } \\
\text { of entities }\end{array}$ & $\begin{array}{l}\text { Medium } \\
\text { Response for defying integration } \\
\text { requirements. }\end{array}$ \\
\hline
\end{tabular}


software and hardware, makes impossible to use cloud solutions for eGovernment.

- Absence of one point of entrance for all government services. Nowadays to get the service person needs to visit directly the web-portal of corresponding agency, usually by finding it via search engines.

- Absence of unique electronic identifier of citizen. Existing digital signatures are not widely used by the people.

- Undefined holistic state vision for developing eGovernment on each authority level, as a result different cities can use different approaches for defining inhabitants or duplicate some functions of centralized eGovernment systems.

\section{Conclusions}

Developed eGovernment systems have direct impact on business environment in the state and complexity of regulations. Based on computed linear regression we can evaluate the direct impact of eGovernment on simplicity of procedures required for running the business in the state. Starting 2014 the eGovernment boom is observed in Ukraine, majority of the central government institutions are opening the entire registries and statistical data. However absence of holistic strategy of eGovernment development in Ukraine together with obsolete and divergent technical standards creates bureaucratic limits for rapid eGovernment growth.

In addition there are a few issues to be investigated in the further researches. Provided model can be improved by including additional macroeconomic and social parameters, dependencies between the eGovernment and Doing Business sub indexes can be evaluated. More detail investigation should be done on listed stakeholders and their behaviour during implementing the eGovernment projects, possibly using game theory methods.

\section{References}

Azad, B., Faraj, S. \& Goh J. F. (2010). What Shapes Global Diffusion of eGovernment: Comparing the Influence of National Governance Institutions, Journal of Global Information Management, 18, 2, p. 85-104.

Decree of the President of Ukraine №5/2015 from January 12, 2015 "About the Strategy for Sustainable Development" Ukraine-2020" - http://zakon5.rada.gov.ua/laws/show/5/2015

Digital agenda for Europe http://ec.europa.eu/digital-agenda/

Dubov D. V. \& Dubova, S. V. (2006). Basics of eGovernment: tutorial. Centre of Educational Literature

e-Estonia. Digital society. - https://e-estonia.com/components/

eGovernment indicators for benchmarking eEurope - http://ec.europa.eu/newsroom/dae/document.cfm?doc $\mathrm{id}=1189$

Ifinedo, P. \& Singh, M. (2011). Determinants of eGovernment Maturity in the Transition Economies of Central and Eastern Europe, Electronic Journal of e-Government, 9, 2, p. 166-182.

InfoDev (Information for Development Programme) (2004). EGovernment handbook for developing countries. Retrieved May 6, 2006 from http://www.infodev.org

Jeong Chun Hai Ibrahim, Fundamental of Development Administration. Selangor: Scholar Press, 2007 ISBN 978-967-5-04508-0.

Kolisnichenko I. M. (2014). Development of eGovernment in Ukraine: institutional aspect. Bizness-inform, 3 p. 52-57. [Electronic resource]. - Retrieved from: http://nbuv.gov.ua/j-pdf/binf_2014_3_9.pdf

Moon, J. M. (2002). The Evolution of EGovernment among Municipalities: Rhetoric or Reality? Public Administration Review, 62, 4, p. 424-433.

Moon, M. J., Welch, E. W. \& Wong, W. (2005). What Drives Global E-governance? An Exploratory Study at a Macro level. In Proceedings of the 38th. Hawaii International Conference on System Sciences, USA.

Project Management Institute (2013). A Guide to the Project Management Body of Knowledge (PMBOK Guide)—Fifth Edition. ISBN: 9781935589679,583 p.

Shevchuk Oleksandr (2003). "Electronic Ukraine - on the way of formalization” Weekly mirrow. - 04.05. http://www.zn.kiev.ua/

The Cabinet of Ministers of Ukraine № 2250-r of December,132010 “About approval of the concept of e-government in Ukraine".

UN Public Administration Program (2010). United Nations EGovernment Global Reports. Retrieved August 12, 2010 from http://www2.unpan.org/egovkb/global_reports/10report.htm

United Nations Department of Economic and Social Affairs (2014). United Nations E-Government Survey 2014 (PDF). UN. Retrieved 2014-09-16.

West, D. M. (2004). EGovernment and the Transformation of Service Delivery and Citizen Attitudes. Public Administration Review, 64, 1, p. 15-27.

World Bank (2014): “Doing Business 2014, Understanding Regulations for Small and Medium-Size Enterprises”, World Bank Group, 2013, U.S.A.

World Bank Group, Doing Business, Historical Data Sets and Trends Data - http://www.doingbusiness.org/ custom-query 


\section{Владимир ДОВГАНИК}

\section{КАК ЭЛЕКТРОННОЕ ПРАВИТЕЛЬСТВО МОЖЕТ ВЛИЯТЬ НА БИЗНЕС: УКРАИНСКИЙ АСПЕКТ}

Аннотация. Целью данной статьи является оценка влияние электронного правительства влияния на бизнес и определить основные характеристики реализации данных систем в Украине. Методология. Для исследования использовались статистические данные, предоставленные международного Индекса развития Электронного правительства (E-Government Survey) и рейтинг ведения бизнеса (Doing Business). Ha основании полученных данных была построена линейная модель. Метод наименьших квадратов был использован для определения параметров модели линейной регрессии. Анализ имеющихся услуг электронного правительства было сделано, чтобы определить их общие характеристики и заинтересованных сторон системы. Результаты исследования демонстрируют сильную корреляцию связь между Индексом развития Электронного правительства (E-Government Survey) и рейтингом ведения бизнеса (Doing Business). Построенная модель доказывает, прямо пропорциональную связь между двумя индексами, а полученная точность модели разрешает утверждать о ее статистической значимости. Рассмотрено основные подходы к определению термину «электронное правительство», а также классификацию систем электронного правительства. Проанализировано и выявлено основные позитивные влияния от внедрения данных систем, а также вызовы с которыми могут столкнутся бизнес и граждане при роботе с системами электронного правительства. Были определены основные заинтересованные стороны проектов электронного правительства и оценены их возможные влияния на проект. Определено бюрократические барьеры, которые замедляют развитие электронного правительства в Украине. Практическое значение. Поскольку внедрение программного средств для обеспечения административных услуг государства оказывает положительное влияние на простоту ведения бизнеса в стране результаты работы могут быть использованы для определения стратегии реформ для изменения государственного регулирования в различных сферах экономики. Определенный список заинтересованных сторон должен учитывается во время и реализации электронного правительства решения для лучшего понимания реальных потребностей бизнеса. Ценность/оригинальность. Определенная модель позволяет лучше понять связь между государственными правилами и предоставлении административных услуг он-лайн. Впервые в Украине сделан акцент на всех заинтересованных сторонах государственных проектов в сфере информационных технологий, в том числе и профильных негосударственных общественных организациях. Результаты исследований могут быть улучшенные за счет включения в регрессионную модель дополнительных макроэкономических и социальных показателей. Также дополнительных исследований требует анализ взаимодействия заинтересованных лиц проекта на всех этапах проектирования и создания сервисов электронного правительства. Взаимозависимости между заинтересованными лицами могут быть смоделированные, например, с помощью теории игр. 